\title{
PENGARUH LINGKUNGAN KERJA DAN DISIPLIN KERJA SERTA MOTIVASI KERJA TERHADAP KINERJA KARYAWAN
}

\section{EFFECT OF WORK ENVIRONMENT AND WORK DISCIPLINE AND WORK MOTIVATION ON EMPLOYEE PERFORMANCE}

\author{
Abdul Hanafi ${ }^{1}$, Zulkifli ${ }^{2}$ \\ Program Studi Magister Manajemen Program Pascasarjana Universitas Riau Kepulauan \\ abdulhanafi@gmail.com
}

\begin{abstract}
Abstrak
Tujuan dari penelitian ini adalah: 1) untuk mempelajari tentang pengaruh Lingkungan dan Disiplin dan Motivasi terhadap Kinerja; 2) untuk mempelajari tentang pengaruh Lingkungan dan Disiplin dan Motivasi parsial terhadap Kinerja; 3) untuk mempelajari tentang pengaruh Lingkungan dan Disiplin dan Motivasi yang memiliki pengaruh dominan pada jumlah karyawan yang menjadi populasi 60 orang responden oleh spesialis. Pengumpulan data adalah dengan memberikan kuesioner kepada responden, wawancara dengan anggota organisasi, dan juga melihat dokumen yang diperlukan. Data yang dikumpulkan didukung oleh pengujian asumsi dan reliabilitas. Analisis model didukung oleh pengujian asumsi klasik; uji korelasi otomatis multikolobieritas. Untuk mengetahui tentang penentuan koefisien determinasi, pengujian dilakukan dengan melihat koefisien determinasi. Dari data regresi berganda diperoleh garis kemiripan kemiripan: $Y=-1,435+$ 0,330X1 + 0,609X2 + 0,156 X3 + e dan diketahui bahwa hasil uji Hipotesis 1: F hitung adalah 143,958 dengan probabilitas 0,000 dan $F$ tabel $(=0,05 ; d f 1=3 ;$ df 60 ) adalah 2,769, artinya variabel Lingkungan (X1) dan Diciplin (X2) dan Motivasi (X3) secara simultan berpengaruh terhadap kinerja (Y), maka hipotesis pertama diterima. Hipotesis 2: Ditemukan bahwa nilai tcount X1 adalah 3.059 dan nilai ttabel adalah 2003 dan dari akun lebih besar nilai ttabel 2.003, hipotesis kedua adalah variabel lingkungan (X1) dan Diciplin (X2) dan Motivasi (X3) secara parsial efek kinerja (Y) diterima.
\end{abstract}

Kata kunci: Lingkungan, Diciplin, Motivasi, Kinerja Karyawan

\begin{abstract}
The objectives of this research are: 1) to learn about the effect of Environment and Diciplin and Motivation to Performance; 2) to learn about the effect of Environment and Diciplin and Motivation partially to Performance; 3) to learn about the effect of Environment and Diciplin and Motivation that has dominant effect to Performance Where numbers of employee wich become the population are 60 persons respondent by spesialis. Data collection is by giving questionnaire toward respondents, interview upon organization member, and also viewing the document needed. The data collected is supported by assumption and reliability testing. The analysis model is supported by classic assumption testing ; multicolobierity test auto correlation test. To find out the accuracy of the model is by viewing determination coefficient, simultaneous hypothesis testing is taken by $F$ test and partial hypothesis is taken by $t$ test. From the double regression data analysis gained similarity regression line: $Y=-$ $1.435+0.330 X 1+0.609 X 2+0.156 X 3+e$ and founded that Hypothesis test result $1: F$ count is 143.958 with probability 0,000 and $F$ tabel $(=0,05 ; d f 1=3 ; d f 260)$ is 2.769, it mean that Environment (X1) and Diciplin (X2) and Motivation (X3) variables is simultan having effect to performance (Y), then the first hypothesis is accepted. Hypothesis 2: Found that the value of tcount X1 is 3.059 and the value of ttabel is 2.003 and than tcount bigger the value ttabel 2.003, the second hypothesis is which stated about Environment (X1) and Diciplin (X2) and Motivation (X3) variable is partially effect the performance ( $Y$ ) is accepted.
\end{abstract}

Keyword: Environment, Diciplin, Motivation, Employee Performance

\section{PENDAHULUAN}

Tumbuh dan berkembangnya organisasi tergantung pada sumber daya manusia. Oleh karena itu sumber daya manusia merupakan aset yang harus ditingkatkan secara efektif dan efisien sehingga akan terwujud kinerja yang optimal. Untuk mencapai dimaksud, organisasi 
dalam hal ini perusahaan harus mampu menciptakan situasi dan kondisi yang mendorong dan memungkinkan karyawan untuk mengembangkan kemampuan dan keterampilan secara optimal, khususnya dalam hal kinerja. Maka organisasi perlu memperhatikan lingkungan kerja dan disiplin serta motivasi karyawan.

Lingkungan kerja adalah segala sesuatu yangadadisekitarparapekerjaandanyangdapat mempengaruhi dirinya dalam menjalankan tugas tugas yang dibebankan (Nitisemito 2012). Faktor lingkungan kerja mempunyai pengaruh terhadap kinerja pegawai adalah iklim organisasi atau lingkungan kerja dimana pegawai tersebut melaksanakan tugas dan tanggung jawabnya. Untuk mengoptimalkan produktivitas karyawan harus tercipta iklim organisasi atau lingkungan yang kondusif sebagai prasyarat peningkatan kinerja pegawai secara maksimal. Adapun faktor-faktor yang mempengaruhi terciptanya iklim organisasi atau lingkungan kerja antara lain adanya kesempatan untuk promosi sesuai dengan prestasinya serta adanya suatu penghargaan dan kekompakkan dalam bekerja. Dikatakan oleh Steers (2015) bahwa bila ingin membahas iklim organisasi sebenarnya berbicara mengenai sifatsifat atau cirri-ciri yang terdapat dalam lingkungan kerja dan timbul terutama karena kegiata organisasi yang dilakukan secara sadar atau tidak yang dianggap mempengaruhi tingkah laku individu kemudian. Dengan demikian maka, iklim dapat dipandang sebagai kepribadian organisasi seperti yang dilihat oleh para anggotanya, jadi bukanlah iklim yang sebenarnya akan tetapi merupakan persepsi dan pengamatan karyawan terhadap situasi organisasi dalam periode tertentu.

Berdasarkan pengamatan peneliti pada PT. ATB masih memerlukan banyak pembenahan. Beberapa ruangan yang ada terlihat kurang penerangannya. Kemudian warna ruangan yang menimbulkan rasa sejuk juga masih kurang. Selanjutnya sirkulasi udara yang ada belum maksimal. Dari sisi kerapian tata ruang masih kurang maksimal, karena masih ditemui penataan berkas kerja yang tidak rapi.

Situasi organisasi dalam periode tertentu ini erat kaitannya dengan aturan main yang ada. Sehingga tidak bisa dipisahkan dari kedisiplinan para karyawan. Menurut (Moenir dalam Tollardi, 2012), disiplin adalah sendiri adalah ketaatan terhadap aturan. Sementara disiplinisasi adalah usaha yang dilakukan untuk menciptakan keadaan disuatu lingkungan kerja yang tertib, berdaya guna dan berhasil guna melalui suatu system pengaturan yang tepat. 
Berdasarkan pendapat-pendapat di atas, maka dapat disimpulkan bahwa disiplin kerja adalah suatu keadaan tertib dimana seseorang atau sekelompok orang yang tergabung dalam organisasi tersebut berkehendak mematuhi dan menjalankan peraturan peraturan perusahaan baik yang tertulis maupun tidak tertulis dengan dilandasi kesadaran dan keinsyafan akan tercapainya suatu kondisi antara keinginan dan kenyataan dan diharapkan agar para karyawan memiliki sikap disiplin yang tinggi dalam bekerja sehingga produktivitasnya meningkat.

Pengamatan yang dilakukan peneliti terhadap karyawan PT. ATB tingkat kehadiran yang ada fluktuatif dan belum sepenuhnya karyawan berdisplin untuk masuk kerja sebagai suatu kewajiban tanpa harus ada paksaan. Perputaran atau rotasi karyawan yang dilakukan ada yang terjadi terlalu cepat, sedangkan untuk kehadiran karyawan sebagian ada yang tidak tepat waktu atau terlambat.

Soemidjo (2014) menjelaskan motivasi merupakan proses psikologis yang mencerminkan interaksi antara setiap kebutuhan, persepsi dan keputusan yang terjadi pada seseorang yang timbulnya disebabkan oleh faktor dari dalam diri orang itu sendiri dan faktor dari luar diri seseorang. Pendapat tersebut tidak jauh dari teori Maslow yang mengemukakan bahwa hirarkhi kebutuhan manusia dapat digunakan untuk melukiskan dan mengambarkan motivasi kerja seseorang. Dimana kebutuhan seseorang dimaksud meliputi kebutuhan fisiologis, keselamatan atau keamanan, akan hak milik, kecintaan dan kebutuhan akan harga diri serta kebutuhan akan aktualisasi diri.

Faktor penting lain yang mempunyai pengaruh terhadap kinerja pegawai adalah iklim organisasi atau lingkungan kerja dimana pegawai tersebut melaksanakan tugas dan tanggung jawabnya. Dimana untuk mengoptimalkan kinerja pegawai harus tercipta iklim organisasi atau lingkungan yang kondusif sebagai prasyarat peningkatan kinerja pegawai secara maksimal. Adapun faktor-faktor yang mempengaruhi terciptanya iklim organisasi atau lingkungan kerja antara lain adanya kesempatan untuk promosi sesuai dengan prestasinya serta adanya suatu penghargaan dan kekompakkan dalam bekerja. Seperti dikatakan oleh Steers (2015) bahwa bila ingin membahas iklim organisasi, sebenarnya berbicara mengenai sifat-sifat atau cirri-ciri yang terdapat dalam lingkungan kerja dan timbul terutama karena kegiata organisasi yang dilakukan secara sadar atau tidak yang dianggap mempengaruhi tingkah laku individu kemudian. Dengan demikian maka, iklim dapat dipandang sebagai kepribadian organisasi seperti yang dilihat oleh para anggotanya, jadi bukanlah iklim yang 
sebenarnya akan tetapi merupakan persepsi dan pengamatan karyawan terhadap situasi organisasi dalam periode tertentu.

Dalam hal motivasi kerja, pengamatan peneliti terhadap karyawan PT. ATB khususnya terhadap penghargaan dengan memberikan kesempatan melanjutkan studi masih kurang, sehingga karyawan tidak termotivasi untuk mengembangkam skill yang ada pada dirinya. Untuk kreativitas dalam melaksanakan tugasnya, masih belum memperoleh perhatian karena karyawan cenderung untuk melaksanakan tugas sebatas gugur kewajiban.

Kinerja merupakan tindakan-tindakan atau pelaksanaan tugas yang dilakukan oleh seseorang dalam kurun waktu tertentu dan dapat diukur. Hasibuan (2010) menyatakan bahwa prestasi kerja adalah suatu hasil kerja yang dicapai seseorang dalam melaksanakan tugastugas yang dibebankan kepadanya yang didasarkan kecakapan, pengalaman dan kesungguhan. Lebih lanjut dikemukakan bahwa prestasi kerja atau kinerja ini merupakan gabungan dari tiga faktor penting yaitu: 1) kemampuan dan minat seorang karyawan, 2) kemampuan dan penerimaan atas penjelasan delegasi tugas dan 3) peran serta tingkat motivasi seorang karyawan. Semakin tinggi ketiga faktor tersebut, maka semakin tinggi besarlah prestasi kerja karyawan yang bersangkutan. Kinerja yang tinggi merupakan manifestasi dari kualitas karyawan. Kinerja ini merupakan suatu hal yang penting dalam rangka menunjang kelancaran organisasi dalam mencapai tujuanya dan dapat tercipta jika terdapat semangat yang tinggi dari para karyawannya

Hal ini juga berlaku bagi karyawan PT. ATB dalam mengerjakan pekerjaannya, bagaimana karyawan dapat melaksanakan pekerjaannya dengan baik-baiknya dan kualitas yang dapat ditingkatkan, serta dapat mencapai kinerja yang maksimal. Berdasarkan pengamatan peneliti, kinerja pada karyawan PT. ATB masih belum optimal. Kemampuan dan minat yang berbeda dan bertolak belakang dengan tugas yang ada sekarang memicu tidak maksimalnya kinerja yang ada. Dari sisi kwantitas dan kwalitas pekerjaan yang meliputi standart waktu yang digunakan masih perlu di tingkatkan lagi.

Oleh sebab itu, maka dilakukan penelitian dengan judul Pengaruh Lingkungan Kerja dan Disiplin Kerja serta Motivasi Kerja Terhadap Kinerja Karyawan.

\section{Rumusan Masalah}

Berdasarkan latar belakang di atas, maka dapat dibuat rumusan permasalahan sebagai berikut: 
1. Apakah lingkungan kerja dan disiplin kerja serta motivasi kerja secara simultan berpengaruh signifikan terhadap kinerja karyawan?

2. Apakah lingkungan kerja dan disiplin kerja serta motivasi kerja secara parsial berpengaruh signifikan terhadap kinerja karyawan?

\section{Tujuan Penelitian}

1. Untuk mengetahui dan membuktikan pengaruh lingkungan kerja dan disiplin kerja serta motivasi kerja secara simultan terhadap kinerja karyawan.

2. Untuk mengetahui dan membuktikan pengaruh lingkungan kerja dan disiplin kerja serta motivasi kerja secara parsial terhadap kinerja karyawan.

\section{Tinjauan Pustaka}

\section{Lingkungan Kerja}

Lingkungan adalah keseluruhan atau setiap aspek dan gejala fisik dan sosial kultural yang mempengaruhi individu. Kerja adalah aktifitas manusia baik fisik maupun mental yang 2011). Dengan demikian dapat disimpulkan bahwa lingkungan kerja adalah segala sesuatu yang ada disekitar para pekerjaan dan yang dapat mempengaruhi dirinya dalam menjalankan tugas tugas yang dibebankan (Nitisemito 2012).

Lingkungan kerja sebagai sumber informasi dan tempat melakukan aktifitas, maka kodisi lingkungan kerja yang baik haras dicapai agar karyawan merasa betah dan nyaman di dalam ruangan untuk menyelesaikan pekerjaan sehingga dapat efisiensi yang tinggi. Lingkungan kerja yang baik akan membawa dampak pada meningkatnya kualitas pekerjaan, mengurangi ketenangan pada mata dan keinginan rohaniah, serta yang terpenting semangat kerja lebih baik dan prestise yang lebih baik untuk instansi yang bersangkutan.

\section{Disiplin Kerja}

Pada umumnya disiplin yang baik terdapat apabila karyawan datang ke kantor atau perusahaan dengan teratur dan tepat pada waktunya, apabila mereka berpakaian serba baik pada tempat pekerjaannya, apabila menggunakan bahan bahan dan perlengkapan dengan hati hati, apabila mereka menghasilkan jumlah dan kualitet pekerjaan yang memuaskan, dan mengikuti cara keria yang ditentukan oleh perusahaan dan apabila menyelesaikan dengan semangat yang baik. (Tie, dalam Kerlnyer and Pedbazur, 2017).

Disiplin merupakan keadaan yang menyebabkan atau memberikan dorongan kepada karyawan untuk berbuat dan melakukan segala kegiatan sesuai dengan norma norma atau aturan aturan yang telah ditetapkan. 
Pengertian disiplin kerja adalah suatu ketaatan karyawan terhadap suatu aturan atau ketentuan yang berlaku dalam suatu perusahaan atas dasar adanya kesadaran atau keinsyafan bukan adanya unsur paksaan (Wursanto, 2010).

Menurut (Moenir dalam Tollardi, 2012), disiplin adalah sendiri adalah ketaatan terhadap aturan. Sementara disiplinisasi adalah usaha yang dilakukan untuk menciptakan keadaan disuatu lingkungan kerja yang tertib, berdaya guna dan berhasil guna melalui suatu system pengaturan yang tepat.

Sebagaimana pendapat dimaksud disiplin kerja adalah suatu keadaan tertib dimana seseorang atau sekelompok orang yang tergabung dalam organisasi tersebut berkehendak mematuhi dan menjalankan peraturan peraturan perusahaan baik yang tertulis maupun tidak tertulis dengan dilandasi kesadaran dan keinsyafan akan tercapainya suatu kondisi antara keinginan dan kenyataan dan diharapkan agar para karyawan memiliki sikap disiplin yang tinggi dalam bekerja sehingga produktivitasnya meningkat.

\section{Motivasi}

Menurut Jewell. (2010), motivasi mengacu kepada jumlah kekuatan yang mengahasilkan, mengarahkan, dan mempertahankan usaha dalam perilaku tertentu. Robbins (2016) mendefinisikan motivasi merupakan kesediaan untuk mengeluarkan tingkat upaya yang tinggi kearah tujuan organisasi, yang dikondisikan oleh kemampuan itu untuk memenuhi sesuatu kebutuhan individu. Selanjutnya dikemukakan bahwa suatu keadaan internal yang menyebabkan hasil hasil tertentu tampak menarik.

Secara fisik manusia merupakan mahluk yang paling sempurna dibandingkan dengan mahluk $\neg$ mahluk ciptaan Tuhan lainnya. Secara psikis atau mental manusia mempunyai kemungkinan tanpa batas untuk berkembang.

Dalam melakukan kegiatan pada lazimnya, manusia memiliki tujuan yaitu terarah demi meraih suatu hasil atau sasaran yang diharapkan. Tujuan kegiatan dalam psikologi disebut motif dan tujuan disebut arah yang akan dicapai dengan melalui sasaran sasaran.

Kemampuan untuk memotivasi bawahan adalah merupakan keterampilan manejerial yang perlu dikuasai oleh setiap manajer organisasi. Dengan memahami peranan penting motivasi, manajer akan dapat mengembangkan prestasi kerja bawahannya dan dapat meningkatkan kepuasan kerjanya (Sujak, 2010).

Untuk mencapai keberhasilan ini perlu mempertimbangkan apa yang dapat dikerjakan untuk mendorong individu berusaha sebaik baiknya guna kepentingan organisasi dan 
kepentingan mereka sendiri. Hal ini berarti motivasi merupakan sesuatu yang menggerakkan orang. Memberi motivasi berhubungan dengan kepastian bahwa orang bergerak kearah yang diinginkan, dengan demikian maka sasaran motivasi adalah untuk mencapai rasa memiliki bahwa sejauh mungkin keinginan dan kebutuhan para anggotanya berada dalam keadaan yang harmonis.

Keinginan dapat dianggap sebagai cara spesifik yang terpengaruh oleh lingkungan dengan apa kebutuhan tersebut dipenuhi. Dalam memenuhi kebutuhan itu tentu akan terdapat penghalang. Untuk dapat memenuhi suatu penghalang dalam rangka usaha mencapai tujuan adalah dengan melakukan penyesuaian - penyesuaian. Jika orang tidak dapat menyesuaikan maka akan timbul ketegangan dan bila tidak dapat mengurangi ketegangan akan menimbulkan frustasi. Untuk itu digunakan pertahanan seperti agresi agresi, mengundurkan diri dan kompromis.

Motivasi merupakan suatu elemen psikologis, sedangkan kerja merupakan suatu kegiatan yang komplek dalam hal bentuk, sifat, sasaran harapan dan realitas. Pegawai masih harus dipejelas dalam kontek kontek ruang waktu insani.

Motivasi dasar manusia adalah fisiologikal demi memenuhi kebutuhan primer seperti makan dan minum. Di budaya masyarakat masa kini, untuk bias makan dan minum bisa ditempuh melalui mencari nafkah dan cara mencari nafkah dengan bekerja termasuk sebagai pegawai, masalah motivasi tidak sederhana itu lagi, tetapi berkembang lebih komplek ke berbagai aspek.

\section{Kinerja}

Salah satu definisi tentang kinerja karyawan disampaikan oleh Bernandin dan Russel (2013), bahwa kinerja merupakan catatan perolehan yang dihasilkan dari fungsi suatu pekerjaan tertentu atau kegiatan selama suatu periode waktu tertentu.

Apabila prestasi kerja atau produktivitas kerja karyawan setelah mengikuti pengembangan, baik kualitas maupun kuantitas kerjanya meningkat maka berarti metode pengembangan yang ditetapkan cukup baik, Hasibuan (2011).

Dalam proses organisasi yang khas, tiap manajer mengalami penimbangan prestsi berkala. Seperti halnya dengan segi segi lain dari pembinaan manajemen, tujuan utama dari penimbangan tahun tahun ikhir akhir ini telah berubah. Penimbangan ini pada mulanya merupakan suatu alat untuk memberikan pedoman bagi manajemen dalam menseleksi para 
manajer untuk promosi atau kenaikan gaji, tetapi sekarang juga digunakan untuk melatih para manajer guna memperbaiki prestasi mereka, Strauss dan Sayles (2011).

Swasto (2016) mengemukakan bahwa prestasi kerja merupakan tindakan tindakan atau pelaksanaan tugas yang telah diselesaikan, oleh seseorang dalam kurun waktu tertentu dan dapat diukur. Hal ini dapat berkaitan dengan jumlah kuantitas dan kualitas pekerjaan yang dapat diselesaikan oleh individu dalam kurun waktu tertentu.

Ada beberapa cara untuk mengukur prestasi kerja. Prestasi kerja dapat diukur secara umum yaitu:

1. Kuantitas kerja

2. Kualitas kerja

3. Pengetahuan tentang pekerjaaan

4. Pendapat atau pemyataan yang disampaikan

5. Keputusan yang diambil

6. Perencanaan kerja

7. Daerah organisasi kerja

Jadi prestasi kerja berkenan dengan hasil pekerjaan yang dicapai oleh karyawan dalam suatu periode. Dalam hal ini prestasi kerja berkaitan dengan kuantitas maupun kualitas pekerjaan yang dihasilkan.

Bagai mana untuk mengetahui kinerja karyawan, Heneman, Schwab dan Fossum (1991) mengemukakan bahwa secara umum pengukuran kinerja mencakup dua kegiatan :

1. Identifikasi dimensi prestasi kerja.

2. Penetapan standar prestasi kerja.

Dharma (2012) mengemukakan bahwa hampir seluruh cara pengukuran dimensi prestasi kerja mencakup semua unsur yang akan dievaluasi dalam pekerjaan masing masing karyawan dalam suatu organisasi. Dimensi ini mencakup berbagai kriteria yang sesuai untuk digunakan dalam mengukur hasil pekerjaan yang kinerja mempertimbangkan hal hal sebagai berikut:

1. Kuantitas, yaitu jumlah yang harus diselesaikan..

2. Kualitas,yaitu mutu yang dihasilkan.

3. Ketepatan waktu, yaitu kesesuaian dengan waktu yang telah direncanakan.

Tidak semua kriteria pengukuran kinerja dipakai dalam suatu penilaian kinerja karyawan, tentu hal ini harus disesuaikan dengan jenis pekerjaan yang akan dinilai. 
Bernandian dan Russet, (2015), mengajukan enam kriteria primer yang dapat digunakan untuk mengukur kinerja:

1. Quality, merupakan tingkat sejauh mana proses atau hasil pelaksanaan kegiatan mendekati kesempurnaan atau mendekati tujuan yang diharapkan.

2. Quantity, merupakan jumlah yang dihasilkan, misalnya jumlah rupiah, jumlah unit, jumlah siklus kegiatan yang diselesaikan.

3. Time liness, adalah tingkat sejauh mana suatu kegiatan diselesaikan pada waktu yang dikehendaki, dengan memperhatikan koordinasi out put lain serta waktu yang tersedia untuk kegiatan lain.

4. Cost effectiveness, adalah tingkat sejauh mana penggunaan daya organisasi (manusia, keuangan, tehnologi, material dimaksimalkan) untuk mencapai hasil tertinggi, atau pengurangan kerugian dan setiap inti penggunaan sumber daya.

5. Need for supervision, merupakan tingkat sejauh mana seorang pekerja dapat melaksanakan suatu fungsi pekerjaan tanpa memerlukan pengawasan seseorang supervisor untuk mencegah tindakan yang kurang diinginkan.

6. Interpersonal Impact, merupakan tingkat sejauh mana karyawan memelihara harga diri, nama baik dan kerja sama diantara rekan kerja dan bawahan.

Penetapan standar diperlukan untuk mengetahui apakah kinerja karyawan telah sesuai dengan sasaran yang diharapkan, sekaligus melihat besarnya penyimpangan dengan cara membandingkan antara hasil pekerjaan secara actual dengan hasil yang diharapkan. Standar, menmurut Snow dan Alexander (2012) merupakan tolok ukur bagi kinerja yang akan dievaluasi.

\section{METODOLOGI}

\section{Rancangan Penelitian}

Rancangan yang digunakan dalam penelitian ini adalah dengan metode survey yang ditujukan untuk memberikan penjelasan mengenai fenomena yang diteliti dan hubungan antar variabel, atau dengan kata lain dapat pula disebutkan bahwa penelitian ini termasuk ke dalam penelitian explanatory. Pemilihan rancangan penelitian ini didasarkan pada kemampuan yang ada, sedangkan instrumen yang diandalkan adalah berupa angket.

\section{Ruang Lingkup Penelitian}

Penetapan ruang lingkup penelitian yang dilakukan ini adalah didasarkan pada pertimbangan antara lain: waktu, biaya, maksud dan tujuan penelitian, kerangka teori yang 
digunakan serta faktor keterbatasan peneliti. Penelitian ini mempunyai ruang lingkup tentang pengkajian lingkungan kerja dan disiplin kerja serta motivasi kerja terhadap kinerja karyawan PT. ATB.

\section{Obyek Penelitian}

Dalam penelitian ini, hipotesis yang telah dirumuskan akan diuji untuk mengetahui Lingkungan Kerja, Disiplin Kerja serta Motivasi Kerja sebagai variabel bebas berpengaruh terhadap kinerja karyawan PT. ATB sebagai variabel terikat.

\section{Sumber dan Jenis Data}

Pengumpulan data dalam penelitian ini digunakan satu sumber dan dua jenis data, yang diantaranya meliputi:

\section{Sumber Data}

Sumber data yang digunakan pada penelitian ini satu sumber data yaitu data internal PT. ATB berupa pengumpulan kuisioner, data-data yang diterbitkan. Untuk jenis data terdiri dari:

\section{a. Data Primer}

Adapun untuk mengumpulkan data yang diperlukan untuk memenuhi kebutuhan penelitian ini, data diperoleh dari penyebaran angket kepada responden dimana pertanyaan terlebih dahulu disediakan oleh peneliti. Untuk mendukung data data dan informasi melalui angket tersebut peneliti juga mengadakan wawancara langsung kepada responden yang dijadikan obyek penelitian.

b. Data Sekunder

Dalam rangka untuk mendukung data penelitian disamping melalui angket dan wawancara, maka peneliti mendapatkan data administratif yang diperoleh dari dokumen dokumen pada PT. ATB seperti dokumen Peraturan Perundang Undangan, laporanlaporan dan buku buku yang berkaitan dengan pokok masalah dalam penelitian ini.

\section{Variabel Penelitian}

Variabel bebas (independent) merupakan variabel yang dapat mempengaruhi lainnya atau dapat diartikan sebagai variabel penyebab (Arikunto, 20169). Adapun variabel bebas dalam penelitian adalah:

1. Variabel $\mathrm{X} 1$ Lingkungan Kerja, terdiri dari lima indikator variabel yaitu

(Penerangan X1.1, Warna Ruangan X.1.2, Suasana X.1.3, Udara X.1.4, Tata Ruang Kantor X1.5). 
2. Variabel X2 Disiplin Kerja terdiri dari empat indikator yaitu (Tingkat Absensi X2.1, Perputaran Tenaga Kerja X2.2, Kelambatan Kerja X2.3 dan Kesalahan Kerja X2.4)

3. Variabel X3 Motivasi Kerja terdiri dari lima indikator yaitu (Kebutuhan Fisik X3.1, Kebutuhan Rasa Aman X3.2, Kebutuhan Sosial X3.3, Kebutuhan Penghargaan X3.4, Kebutuhan Aktualisasi Diri X3.5)

4. Variabel Y Kinerja Karyawan meliputi beberapa indicator variabel yaitu (Kuantitas Y1.1, Kualitas Y.1.2, Waktu Y1.3)

\section{Instrumen Penelitian}

Adapun pengukuran yang digunakan untuk mengetahui pengaruh variabel variabel tersebut adalah ukuran ordinal. Ukuran ordinal tersebut dikerjakan melalui penyusunan skala dengan teknik pengukuran angket. Dalam penelitian ini tanggapan responden diukur dengan mengunakan skala Likert yang telah disesuaikan dengan kondisi responden, yaitu dengan memberikan 4 (empat) pilihan jawaban untuk satu pertanyaan. Skor tersebut bergeser antara nilai 1 (satu) sampai dengan 4 (empat) dengan pertimbangan bahwa untuk menghindari kecenderungan responden yang tidak secara tegas memilih antara setuju dengan tidak setuju.

Menurut Sugiono (2010) alternatif penilaian skala likert terdiri dari 3 (tiga), 4 (empat) dan 5 (lima) pilihan dengan gradasi sangat positif sampai dengan negative. Di mana dalam penelitian ini menggunakan 4 (empat) alternatif pilihan:
a. Apabila jawaban A diberi nilai $4=$ sangat setuju
b. Apabila jawaban B diberi nilai $3=$ setuju
c. Apabila jawaban $\mathrm{C}$ diberi nilai $2=$ tidak setuju
d. Apabila jawaban D diberi nilai $1=$ sangat tidak setuju

Metode yang digunakan untuk mengukur pengaruh yang akan diteliti melalui tanggapan responden terhadap pertanyaan pertanyaan yang disajikan. Kuisioner dalam studi ini dipakai sebagai dasar analisa yang utama dilakukan lebih tertumpu pada skor responden pada tiap tiap pengamatan. Benar tidaknya skor responden tergantung pada baik tidaknya pengumpulan data.

\section{PEMBAHASAN}

\section{Pengujian Hipotesis}

Setelah pengolahan data yang dilakukan secara deskriptif dan perhitungan regresi linear berganda, kemudian akan dilakukan pengujian terhadap hipotesis. Pengujian hipotesis ini menggunakan tingkat signifikansi $(\alpha)$ sebesar 0,05 atau 5\%. 


\section{Pengujian Hipotesis 1}

Hipotesis 1 berbunyi: Diduga bahwa lingkungan kerja dan disiplin kerja serta motivasi kerja secara simultan berpengaruh signifikan terhadap kinerja karyawan PDAM Kota Batam. Untuk menguji hipotesis tersebut maka dapat digunakan uji F seperti pada Tabel berikut:

Hasil Perhitungan Uji F

ANOVAb

\begin{tabular}{|c|c|c|c|c|c|c|}
\hline Model & & $\begin{array}{l}\text { Sum of } \\
\text { Squares }\end{array}$ & df & Mean Square & $\mathrm{F}$ & Sig. \\
\hline \multirow[t]{3}{*}{1} & Regression & 339.333 & 3 & 113.111 & 143.958 & $.000 \mathrm{a}$ \\
\hline & Residual & 44.000 & 56 & .786 & & \\
\hline & Total & 383.333 & 59 & & & \\
\hline
\end{tabular}

b. Dependent Variable: KINERJA KARYAWAN

Sumber: Data primer diolah

Dari hasil perhitunagan uji $\mathrm{F}$ pada tabel 4.18 diperoleh $\mathrm{F}_{\text {hitung }}$ sebesar 143.958 dengan probabilitas 0,000 dan $F_{\text {tabel }}$ pada taraf nyata $(=0,05$; df $1=3$; df $2=60)$ sebesar 2.769. Karena tingkat signifikansi $\alpha<5 \%(0.000<0.005)$ dan Fhitung $>$ Ftabel, (143.958 >2.769), maka dapat disimpulkan bahwa H0 ditolak dan Ha diterima. Dengan demikian bahwa ada pengaruh yang signifikan dari variabel lingkungan kerja, disiplin kerja dan motivasi kerja secara simultan berpengaruh terhadap kinerja karyawan, maka hipotesis 1 diterima.

\section{Pengujian hipotesis 2}

Hipotesis 2 berbunyi: Diduga bahwa lingkungan kerja dan disiplin kerja serta motivasi kerja secara parsial berpengaruh terhadap kinerja karyawan PT. ATB. Untuk menguji hipotesis tersebut dapat digunakan uji t sebagaimana terlihat pada tabel berikut. Dengan mengunakan uji t untuk mengetahui pengaruh masing-masing variabel bebas secara parsial terhadap kinerja pegawai, maka digunakan Korelasi Partial yaitu dengan membandingkan nilai $t_{\text {hitung }}$ dan $t_{\text {tabel. }}$. Apabila nilai $t_{\text {hitung }}$ lebih besar dari $t_{\text {tabel, }}$ maka $\mathrm{H}_{\mathrm{o}}$ ditolak dan $\mathrm{H}_{\mathrm{a}}$ diterima, demikian pula sebaliknya.

Untuk menguji apakah peningkatan koefisien regresi diatas mempunyai pengaruh secara parsial maka dilakukan pengujian dengan hasil sebagai berikut: 


\section{Rekapitulasi Hasil Uji t}

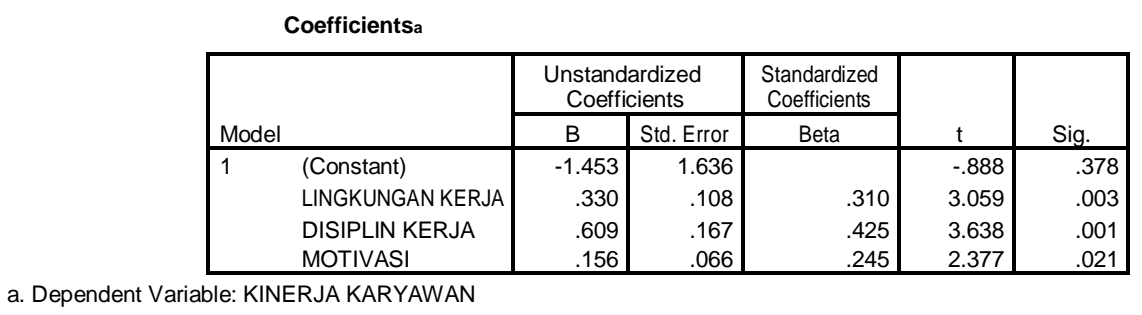

Sumber: Data primer diolah

a. Nilai $t_{\text {hitung }} \mathrm{X} 1$ diketahui sebesar 3.059 dimana selanjutnya dibandingkan dengan nilai ttabel sebesar 2.003. Dengan demikian terlihat thitung lebih besar dari $\mathrm{t}_{\text {tabel }}(3.059>2.003)$ maka menerima $\mathrm{H}_{0}$ dan menolak $\mathrm{H}_{1}$. Jadi dapat dikatakan variabel lingkungan kerja berpengaruh signifikan terhadap kinerja karyawan PDAM Kota Batam.

b. Nilai $t_{\text {hitung }} \mathrm{X}_{2}$ diketahui sebesar 3.638 dimana selanjutnya dibandingkan dengan nilai $t_{\text {tabel }}$ sebesar 2.003. Pada tahap komparasi tersebut mengindikasikan bahwa nilai $t_{\text {hitung }}>$ $\mathrm{t}_{\text {tabel }}(3.638>2.003)$. Jadi dapat dikatakan variabel disiplin kerja berpengaruh signifikan terhadap kinerja karyawan PDAM Kota Batam.

c. Nilai thitung $\mathrm{X}_{3}$ diketahui sebesar 2.377 dimana selanjutnya dibandingkan dengan nilai ttabel sebesar 2.003. Pada tahap komparasi tersebut mengindikasikan bahwa nilai $t_{\text {hitung }}$ $>\mathrm{t}_{\text {tabel }}(2.377>2.003)$. Jadi dapat dikatakan variabel motuvasi berpengaruh signifikan terhadap kinerja karyawan PDAM Kabupaten Lumajang. Dengan demikian hipotesis 2 yang berbunyai: Bahwa lingkungan kerja dan disiplin kerja serta motivasi kerja berpengaruh signifikan secara parsial terhadap kinerja karyawan PT. ATB dapat diterima.

\section{Pembahasan}

Tanggapan karyawan PT. ATB terhadap tuntutan pekerjaan dapat berbeda-beda antara satu dengan lainnya. Responden atau karyawan memiliki karakteristik pribadi tertentu. Hasil penelitian ini menunjukkan bahwa lingkungan kerja dan disiplin kerja serta motivasi kerja secara bersama-sama membawa pengaruh terhadap kinerja karyawan PT. ATB. Hal ini ditunjukkan dengan hasil penelitian tingkat koofisien determinasi sebesar R2=0.885.

Dalam penelitian ini dilakukan kajian untuk memperoleh kinerja karyawan PT. ATB. Salah satu faktor penting dalam hal ini adalah lingkungan kerja. Menurut As'ad (2011) lingkungan kerja adalah keseluruhan atau setiap aspek dan gejala fisik dan sosial kultural yang mempengaruhi individu. Nitisemito (2012) menyatakan lingkungan kerja adalah segala 
sesuatu yang ada di sekitar para pekerjaan dan yang dapat mempengaruhi dirinya dalam menjalankan tugas-tugas yang dibebankan.

Setelah diputuskan bahwa hipotesis penelitian ini baik secara simultan maupun parsial lingkungan kerja (X1) memberikan pengaruh yang signifikan terhadap kinerja, hal ini juga dapat diketahui berdasarkan jawaban responden pada tabel statistik deskriptif menunjukan mayoritas responden mengatakan lingkungan kerja sudah baik. Hal ini seperti ditunjukan pada rata-rata item pertanyaan dari variabel lingkungan kerja, responden mayoritas menjawab setuju sebesar $87.67 \%$.

Karyawan PT. ATB sebagai komponen dalam kegiatan pembelajaran disekolah mempunyai peranan yang menentukan terhadap pencapaian tujuan perusahaan. Untuk dalam memberikan pelayanan kepada masyarakat, karyawan harus mempunyai kinerja yang baik maka perlu ditunjang disiplin kerja. Disiplin kerja merupakanm dan atau membuat motivasi seseorang untuk mempunyai komitmen yang tinggi dalam mencapai tujuan yang ada dalam organisasi tersebut. Disiplin kerja dapat memberikan suatu dinamika kehidupan dalam organisasi dan sangat berpengaruh terhadap sumber daya manusianya (Suyanto 2017). Elemen-elemen seperti sikap, nilai-nilai serta motuf-motif yang dimiliki seseorang individu mempunya peranan penting dalam proses konseptual iklim organisasi.

Apabila disiplin kerja dirasakan sebagai sesuatu yang bermanfaat bagi kebutuhan individu, misalnya memperhatikan kepentingan karyawan dan berorientasi pada prestasi, maka dapat diharapkan tingkat perilakunya mengarah pada tujuan yang tinggi. Demikian pula apabila iklim yang timbul bertentangan dengan tujuan, kebutuhan dan motivasi probadi, akan dapat mengakibatkan kepuasaan dan kinerja menurun (Steers, 2015).

Penerapan kedispilinan karyawan merupakan hal yang menarik karena dengan alasan dan karakteristik pemegang komando kedisiplinan akan takut melawan arus karena penerapan hukuman dan pemberian sanksi yang tegas kepada pelanggar disiplin kerja. Ada pun kedisiplinan akan berhasil jika. penerapannya ditunjang dengan beberapa perangkat reward dan punshisment seperti pendapat Dessler dalam Hasibuan (2010) faktor-faktor yang menunjang dalam rangka penerapan disiplin kerja yaitu:

a. Tujuan dan Kemampuan

Tujuan dan kemampuan mempengaruhi tingkat kedisiplinan karyawan. Tujuan yang akan dicapai harus jelas dan ditetapkan secara ideal serta cukup menantang bagi kemampuan pegawai. Hal ini berarti bahwa tujuan pekerjaan yang dibebankan kepada 
seseorang harus sesuai dengan kemampuannya agar dia bekerja secara sunggu-sungguh dan berdisiplin baik untuk mengerjakannya. Tetapi apabila pekerjaan itu di luar tingkat kemampuannya maka kesungguhan dan kedisiplinan karyawan akan rendah.

b. Teladan pimpinan

Telada pemimpin sangat berperan dalam menentukan kedisiplinan karema ia adalah contoh dan panutan bagi karyawan. Pemimpin harus dapat memberikan contoh yang baik, berdisiplin baik, jujur, adil serta sesuai antara ucapan dan perbuatan. Dengan teladan pemimpin yang baik, maka kedisiplinan bawahan akan menjadi baik pula,

c. Balas jasa

Balas jasa ikut menjadi penentu dan mempengaruhi kedisiplinan, karena balas jasa akan memberikan kepuasan dan kecintaan pegawai terhadap instansi dan atau pekerjaannya. Jika kecintaan karyawan semakin baik terhadap pekerjaannya, maka kedisiplinan mereka akan semakin baik pula. Untuk mewujudkan kedisiplinan yang baik, instansi harus dapat memberikan jasa yang sesuai. Kedisiplinan tidak mungkion baik apabila balas jasa yang mereka terima kurang atau bahkan tidak memuaskan untuk memenuhio

kebutuhan-kebutuhannya beserta keluarganya.

d. Keadilan

Keadilan ikut mendorong terwujudnya kedisiplinan karyawan karena ego dan sifat manusia selalu merasa dirinya penting dan diperlakukan sama dengan manusia lainnya. Pimpinan yang cakap dalam kepemimpinannya selalu berusaha bersikap adil terhadap seluruh bawahannya tanpa kecuali karena ia menyadari bahwa dengan keadilan yang baik akan menciptakan kedisiplinan yang baik pula.

e. Pengawasan Melekat

Pengawasan Melekat atau Waskat adalah tindakan nyata yang paling efektif dalam mewujudkan kedisiplinan karena dengan ini atasan harus aktif dan langsung mengawasi perilaku, moral, sikap, gairah kerja dan kinerja bawahannya supaya ia dapat mengawasi dan memberikan petunjuk jika ada bawahannya yang mengalami kesulitan dalam melakukan pekerjannya.

f. Sanksi hukuman

Sanksi hukuman berperan penting dalam memelihara kedisiplinan karyawan karena dengan adanya sanksi hukuman yang semakin berat, maka karyawan akan menjadi takut 
untuk melanggar peraturan-peraturan yang menjadi komitmen bersama, sikap dan perilaku indisipliner akan berkurang. Meskipun demikian, sebagaimana dikemukakan oleh Cameron (2013) tujuan sanksi-sanksi disiplin adalah untuk memperingatkan karyawan dengan jelas tentang perilaku yang diharuskan dan akibat-akibat pelanggaran yang terus berlanjut.

Sanksi-sanksi disiplin bersifat simbolis, yang berfungsi sebagaitolak ukur untuk menunjukkan tingkat keseriusan pelanggaran.

\section{KESIMPULAN}

Berdasarkan hasil penelitian ini, maka dapat diberikan kesimpulan sebagai berikut:

1. Lingkungan kerja, disiplin kerja, dan motivasi secara simultan berpengaruh terhadap kinerja.

2. Lingkungan kerja, disiplin kerja, dan motivasi secara parsial berpengaruh terhadap kinerja.

\section{REFERENSI}

Anoraga S \& Suyati S. 2015. Psikologi Industri dan Sosial, PT Dunia Pustaka Jaya. Jakarta

As'ad, Moh. 2015. Psikologi Industri. Liberty. Yogyakarta

Anton Dayan, 2016. Pengantar Metode Statistik, LP3ES Jakarta

Dewi Agung Nugraheni, Achmad Sudiro, Eka Afnan Troena. 2015. Pengaruh Motivasi Ekstrensik dan Motivasi Intrinsik Terhadap Kinerja Paramedis Keperawatan (Suatu Studi pada RSUUSD Gambiran Kediri). Kumpulan Artikel Seminar Hasil Penelitian. Program Magister Manajemen Program Pasca Sarjana Universitas Brawijaya.

Eko Agus Alfianto, H Bambang Swasto, Achmad Sudiro. 2014. Pengaruh Kompensasi Terhadap Motivasi, Kemampuan dan Kinerja Karyawan Studi pada Karyawan Bagian Pemimpin Perjalanan Kereta Api PT Kereta Api (Persero) Daerah Operasi VII Surabaya. Jurnal Aplikasi Manajemen, Vol 2. Nomer 1, April 2014.

Gasperz, Vincent, 2018. Manajemen ProduktivitasTotal, Strategi Peningkatan Produktivitas Global. Jakarta: PT. Gramedia Pustaka Utama.

Gangsar Sulistiyo. 2015. Pengaruh Motivasi dan Kepemimpinan serta Iklim Organisasi Terhadap Kinerja Pegawai Badan Kesatuan Bangsa dan Perlindungan Masyarakat Pemerintah Kota Pasuruan. Thesis S-2 Universitas. Widya Gama Malang. Tidak Dipublikasikan. 
Hasibuan H. Melayu S.P, 2013. Organisasi dan Motivasi, Dasar Peningkatan Produktivitas. Jakarta: Bumi Aksara.

Robbin, Stephen, 2016. Perilaku Organisasi: Konsep, Kontaversi, Aplikasi. Edisi Bahasa Indonesia, Alih Bahasa:Pujatmoko, Hudiana. Jakarta: Prenhallindo.

Roger G. Schroeder, 2014. Manajemen Operasi Pengambilan Keputusan dalam Fungsi Operasi, Jilid Dua Edisi Ketiga, Alih Bahasa Tim Penerjemah. Jakarta: Erlangga.

Rusman. Tedi. 2012. Pengaruh Imbalan dan Kepuasan Kerja Terhadap Peningkatan Produktivitas Kerja Karyawan, Thesis, Program Pasca Sarjana, Universitas Padjadjaran. Bandung.

Rahayu. 2012. Pengaruh Motivasi, Kemampuan dan Lingkungan kerja Terhadap Kinerja Pegawai BAPPEDA Kota Pasuruan, Thesis, Program Pasca Sarjana, Universitas Widya Gama Malang. 